\title{
Creation of ASEAN Economic Community (AEC) For Future Automotive Industry
}

\author{
${ }^{1} \operatorname{Dr}(\mathrm{Mrs})$ Muneer Sultana, ${ }^{2}$ Khairul Amilin Ibrahim. \\ 1, 2. International College of Automotive, DRB-HICOM, Automotive Complex, Peramujaya, Industrial Area, \\ Pekan, Pahang. Malaysia.
}

\begin{abstract}
ASEAN Economic Community (AEC) shall be the goal of regional economic integration by 2015. AEC envisages the following key characteristics: (a) a single market and production base, (b) a highly competitive economic region, (c) a region of equitable economic development, and (d) a region fully integrated into the global economy. The AEC areas of cooperation include human resources development and capacity building; recognition of professional qualifications; closer consultation on macroeconomic and financial policies; trade financing measures; enhanced infrastructure and communications connectivity; development of electronic transactions through e-ASEAN; integrating industries across the region to promote regional sourcing; and enhancing private sector involvement for the building of the AEC. The study is prepared based on primary data and secondary data. The primary data has collected through oral interview from stalwarts of automotive industry. The secondary data is collected from the reports of international conference of automotive industry and all existing literature has collected also from internet automotive websites, auto business magazines, e-auto journals etc. Findings of the research reveal that, ASEAN motor vehicles is going to be expanded further in future years. Finally suggestions have been framed and conclusions have been drawn for the study.
\end{abstract}

Key Words: ASEAN, Economic Community, Automotive Industry, International Automotive conference.

\section{Introduction.}

The Association of Southeast Asian Nations is a geo-political and economic organization of ten countries located in Southeast Asia, which was formed on 8 August 1967 by Indonesia, Malaysia, the Philippines, Singapore and Thailand. Since then, membership has expanded to include Brunei, Burma (Myanmar), Cambodia, Laos, and Vietnam. Its aims include accelerating economic growth, social progress, and cultural development among its members, protection of regional peace and stability, and opportunities for member countries to discuss differences peacefully. The ASEAN Leaders adopted the ASEAN Economic Blueprint at the 13th ASEAN Summit on 20 November 2007 in Singapore to serve as a coherent master plan guiding the establishment of the ASEAN Economic Community 2015.he ASEAN Economic Community (AEC) shall be the goal of regional economic integration by 2015. AEC envisages the following key characteristics: (a) a single market and production base, (b) a highly competitive economic region, (c) a region of equitable economic development, and (d) a region fully integrated into the global economy. The AEC areas of cooperation include human resources development and capacity building; recognition of professional qualifications; closer consultation on macroeconomic and financial policies; trade financing measures; enhanced infrastructure and communications connectivity; development of electronic transactions through e-ASEAN; integrating industries across the region to promote regional sourcing; and enhancing private sector involvement for the building of the AEC. In short, the AEC will transform ASEAN into a region with free movement of goods, services, investment, skilled labour, and freer flow of capital. According to the "CEO 360 Degree Perspective of the Automotive Industry in ASEAN" Indonesia, Malaysia, Thailand and Vietnam are demonstrating a compound annual growth (CAGR) of 10.1 percent. Sales in Thailand and Indonesia have reached over 1 million vehicles each, and a significant increase in production is expected based on local demands, with Thai dominance of nearly 2.5 million vehicles produced last year alone. In addition to serving the regional market, ASEAN has assumed a greater role as a global supplier of automotive, and is expected to grow in importance due to a competitive production base with strong competencies in certain product ranges. This will increase substantially not only in terms of economic growth, but also employment and technological advancement. The Philippines is better getting its act together in becoming one of the automotive production centres in ASEAN.

\subsection{Need and Significance of the Study:-}

The auto industry has a long value chain and it can be sliced into a fragmented process, the transportation cost is relatively higher as compared to the value of the final product. Therefore, economies of scale, a sizable domestic market, and the logistic cost must be taken into consideration of the production with 
the production network framework. Automakers began investing and producing in Thailand years ago and have developed domestically the support industries needed to produce the labour-intensive parts for their assembly lines. The local procurement to overseas procurement ratio is very high for autos because manufacturers and assemblers aim to save on transport costs by procuring from domestic sources. In such a case a study has conducted about creation of ASEAN economic community for future automotive industry.

\subsection{Objectives of the Study: -}

(1). To Examine the Comparison of ASEAN Motor Vehicle Production and Sales trend with Selected countries. (2). To Analyse the ASEAN Projected sales of Motor Vehicles in forecasting years.

1.3. Scope of the Study: The study covers the ASEAN countries to the extent of automotive industries, with special emphasis on knowledge of automotive of only ASEAN countries.

1.4. Limitations of the Study:-The study of Creation of ASEAN Economic Community

for future automotive industry is prepared based on secondary data and the secondary data was limited to the extent of the ASEAN automotive industry only.

\section{Previous Studies.}

1. According to Business Monitor International (2008) ${ }^{1}$, "the ASEAN region and the ASEAN Free Trade Agreement (AFTA) have been instrumental in providing a basis for trade and cooperation between not only the member states, but between divisions of the same company in different countries.

2. According to ASEAN Statistics $(2010)^{2}$, reported that in 2009, total ASEAN merchandise trade was $\$ 1.5$ trillion, a slight decrease from $\$ 1.71$ trillion in 2008, and U.S.-ASEAN trade was nearly \$146 billion and 18 percent decrease from 2008.

3. According to Industry forecast report $(2010)^{3}$, demand for motor vehicles in Indonesia picked up sharply between 2003 and 2005, recovering from a slump cause by the Asian Financial Crisis in 199798. However, substantially higher fuel prices, a sharp spike in inflation and higher interest rates all contributed to another collapse in 2006. Demand has since recovered, with an expected sales increase of at least five percent in 2010, as well as a boost in production (which fell by 22 percent in 2009).

4. According to Malaysia Auto report (2010) ${ }^{4}$ In 2009, vehicle sales dropped by 20 percent to 486,061 units from a record high of 607,805 units in 2008. Indonesia overtook Malaysia in 2008 to become to become the second-largest car market in ASEAN behind Thailand, but dropped back behind Malaysia again in 2009.

5. According to ASEAN auto market report (2011) $)^{5}$, Car Ownership in the ASEAN market could rise from some 26 million vehicles at last count to nearly 40 million by 2015 .

6. According to ASEAN auto market report $(2011)^{6}$, three countries dominate the ASEAN auto market i.e. Thailand, Indonesia and Malaysia. They account for more than $90 \%$ of motor vehicle output, for example, their share of unit sales in automotive in 2010 stood at $86 \%$.

7. According to ASEAN automotive supplier report $(2013)^{7}$, the growth of automotive production in the ASEAN region has in tandem spurred the growth of an automotive supplier industry. With very few local automotive suppliers that could initially supply the parts and the quality required by international car makers, international suppliers had to follow suit and supply components locally.

8. According to ASEAN auto market $(2011)^{8}$, reported German automakers currently account for just $1 \%$ of unit sales in the ASEAN countries. This is due in part to the high import tariffs of up to $80 \%$. By training a stronger strategic focus on the region - accompanied by a liberalisation of trade - German firms could benefit more handsomely from the growth in the ASEAN auto market than has hither to been the case. The European Union should therefore push hard to boost free trade with the region. Since the countries with their own vehicle manufacturing facilities will continue endeavouring to protect their local industry and foreign automakers to expand their own local factories.

9. According to Deputy Head of the Heavy Industry Department of Vietnam (2013) ${ }^{9}$, opined that the auto industry could perish if the government does not support it and Vietnam would then totally depending on imports, worsening the trade deficit in the process.

10. According to the Economist $(2009)^{10}$, stated that Despite the global economic downturn, Asia's emerging economies are recovering more quickly than other parts of the world. GDP and industrial production figures for emerging Asian economies have shown an impressive bounce in the second quarter. Singapore's GDP soared 21 percent, Indonesia managed a respectable five percent increase, and other countries in the region are expecting a similar rebound. 


\section{Research Methodology:}

Sources of Data: The validity of any research dependent on the systematic method of data collection sources and its analysis. The study is prepared based on primary data and secondary data. The primary data has collected through oral interview from stalwarts of automotive industry. The secondary data has collected from the reports of international conferences of automotive industry and all existing literature has obtained from internet automotive websites, auto business magazines, and e-auto journals.

Exploration of Data: In exploration of data, to display the occurrence or nonappearance of precise features and to associate and compare facts standards or features midst connected matters with numerous joint features or variables, figures have been equipped and figures are influential communiqué tools-it provides text the concentration of readers, and professionally existent great volumes of composite evidence.

\section{Results and Discussion:}

Figure.1. Comparison of ASEAN Motor Vehicle Production trend with selected countries.

Source: ASEAN Automotive Conference report 2013.

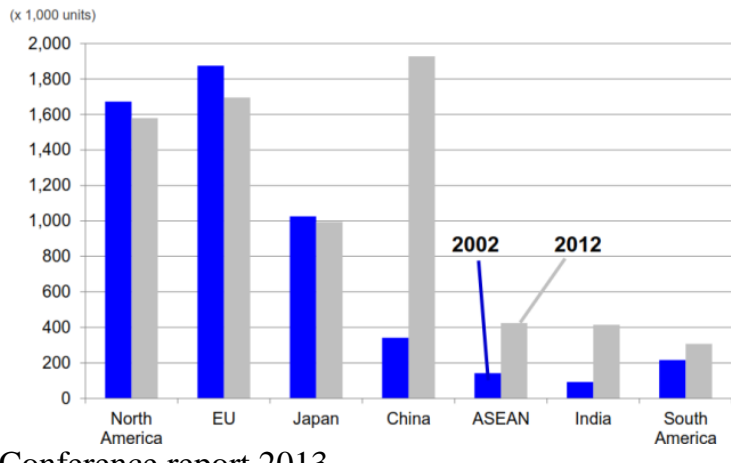

Comparison of ASEAN Motor Vehicle Sales trend with selected countries.

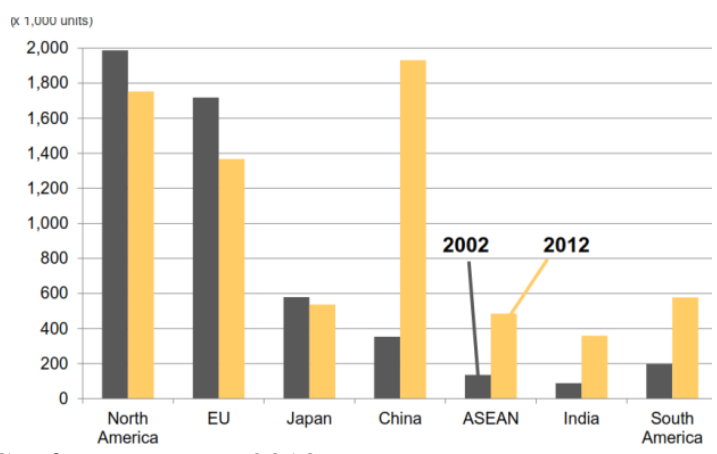

Source: ASEAN Automotive Conference report 2013.

Above figures.4.1. illustrates about the comparison of ASEAN Motor Vehicle Production trend with selected countries. Out of total of seven countries of the world, ASEAN stood at fifth place in both production as well as Sales in Motor Vehicles compared to other world countries during the year 2002 to 2012 years.

Therefore, It can be concluded that, there is an improvement in Motor Vehicle Production and also in Sales since the last 10 years, because of development of automotive technology in Motor Vehicles in ASEAN. 
Figure.2. ASEAN Projected sales of Motor Vehicles in forecasting years.

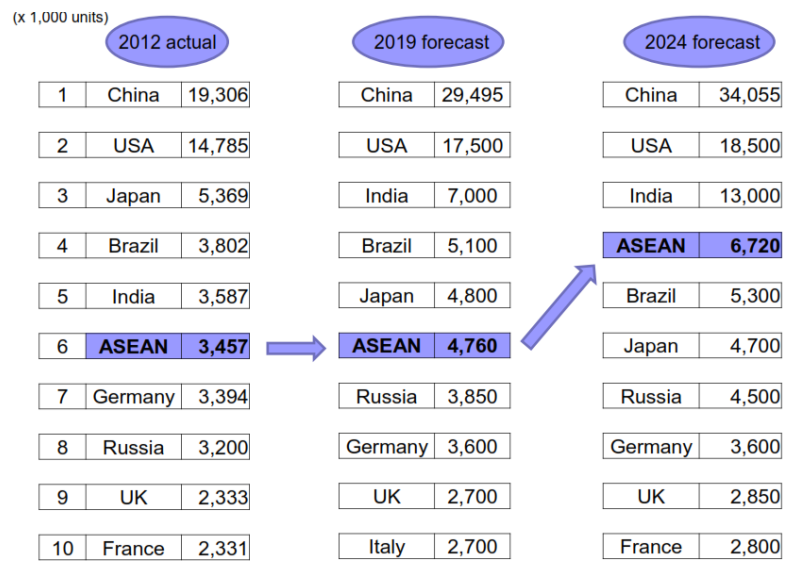

Source: ASEAN Automotive Conference report 2013.

Above figure.4.2. depicts about ASEAN projected sales of Motor Vehicles in Forecasting years. Out of total 10 countries of the world in the year 2012, ASEAN stood at $6^{\text {th }}$ place in sales of Motor Vehicles and projected that, it continues the same in the year 2019 and ultimately, there will be an estimation that by the year 2024, ASEAN will be standing at $4^{\text {th }}$ place in the Market of Motor vehicles. It means Market for Motor Vehicles of ASEAN will be expanded further in future.

Therefore, it can be concluded that, the Creation of ASEAN Economic Community (AEC) for automotive industry will be beneficial for the development of automobiles.

Suggestions: the following are the suggestions for the automotive industry of AEC.

1. Finding out the research reveals that, there is an improvement in the production and sales of Motor vehicles of ASEAN for the Last ten years and also it is projected that ASEAN motor vehicles is going to be expanded further in future years, in such a case ASEAN should create a single regulatory regime for approval and homologation processes to improve time and cost efficiency for motor vehicles. Ultimately, ASEAN should promote to member - countries the introduction of a automotive technology - neutral emission based automotive taxation scheme, such that vehicles with low $\mathrm{CO} 2$ emissions would receive a tax relief where as high- fuel consumption and high $\mathrm{CO} 2$ emission vehicles would be taxed higher, independent of their power train technology. ASEAN Governments should encourage to availability and quality of skilled work force to facilitate public- private partnerships in engineering and technology training to ensure that the work force meets industrial demand.

\section{Conclusion:}

WITH the implementation of the ASEAN Economic Community (AEC) 2015, ASEAN will reach a prominent position to attract foreign investment. As ASEAN is set to become the world's sixth-largest automotive market by 2018, it is expected that regional sales will double to nearly 4.7 million vehicles from 2.4 million last year. Therefore, its 10 member-states continue to facilitate significant investments to flow into this region. A harmonization of standards and regulations has to be seen as essential step to the success of AEC 2015. Only with such a harmonization can the creation of a single manufacturing base as well as free movement of goods be secured.

\section{References:}

[1]. Business Monitor International: Commercial Segment Key Driver of Asian Growth; March 26 2008 , p.5.

[2]. According to ASEAN Statistics (2010), reported that in 2009, total ASEAN merchandise trade was \$1.5 trillion, a slight decrease from \$1.71 trillion in 2008, and U.S.-ASEAN trade was nearly \$146 billion and 18 percent decrease from 2008.

[3]. ASEAN Secretariat: ASEAN Statistics: Selected Basic Economic Indicators; March $15^{\text {th }} 2010$.

[4]. Business Monitor International: Indonesia Auto Report and Malaysia Auto Report Q2, February 2010, p.17.

[5]. Deutsche Bank Research Asia : ASEAN Auto Market September $29^{\text {th }},(2011)$ available

[6]. at : http//www.dbresearch.com

[7]. Deutsche Bank Research Asia : ASEAN Auto Market September $29^{\text {th }}$,(2011) available 
[8]. at : http//www.dbresearch.com

[9]. Dublin - Business Wire : Research and Market, ASEAN Automotive Supplier Report November 2013.

[10]. Deutsche Bank Research Asia : ASEAN Auto Market September $29^{\text {th }},(2011)$ available

[11]. at : http//www.dbresearch.com

[12]. Auto Industry Faces terminal decline with ASEAN tariff elimination august $8^{\text {th }}$ (2013) available at : http// www.thanhniennews.com

[13]. The Economist: On the rebound; August 15 ${ }^{\text {th }} 2009 ; 392(8644): 69-72$. 